motion compared with the analgesic group but there was no difference among the three exercise groups.

In our series the six successes with the functional injection all had considerable relief of pain at one week with more than $50 \%$ improvement in range of motion. Eight of our patients who failed to improve developed signs of cervical spondylosis, which was then taken to account for their persistent shoulder pain, despite their initial examination having shown no signs of that type. We suggest that irritation of the cervical nerve root is a not uncommon cause of shoulder and arm pain and that close attention should be paid to examination of the cervical spine in all patients with shoulder pain.

We are grateful to Dr J Preston and his consultant colleagues in the rheumatology and rehabilitation department, Southampton General Hospital, for allowing us to study their patients.

\section{References}

${ }^{1}$ Cyriax J, Troisier O. Hydrocortone and soft-tissue lesions. Br Med $\mathcal{f}$ 1953 ;ii: $: 966-8$.

${ }^{2}$ Lloyd-Roberts GC, French PR. Periarthritis of the shoulder. Br Med $\mathcal{f}$ $1959 ; \mathrm{i}: 1569-71$
${ }^{3}$ Kessel L, Watson M. The painful arc syndrome. $\mathcal{F}$ Bone foint Surg $1977 ; 59 B: 166-72$.

4 Weiss JJ. Intra-articular steroids in the treatment of rotator cuff tear reappraisal by arthrography. Arch Phys Med Rehabil 1981;62:555-7.

${ }^{5}$ Cyriax J. Rheumatism and soft-tissue injuries. London: Hamilton, 1947.

${ }^{6}$ Cyriax J. Textbook of orthopaedic medicine. Vol 1. London: Baillière, Tindall, 1978.

${ }^{7}$ Cyriax J. Textbook of orthopaedic medicine. Vol 2. London: Baillière, Tindall, 1980.

${ }^{8}$ Travell J, Rinzler SH. The myofascial genesis of pain. Postgrad Med $1952 ; 11: 425-34$.

${ }^{9}$ Sola $\mathrm{AE}$, Kuitert JH. Myofascial trigger point pain in the neck and shoulder girdle. Northwest Medicine 1955;54:980-4.

${ }^{10}$ Coomes EN, Darlington LG. Effects of local steroid injection for supraspinatus tears: controlled study. Ann Rheum Dis 1976;35:943.

${ }^{11}$ Brown BR. Diagnosis and therapy of common myofascial syndromes. FAMA 1978;239:646-8.

${ }^{12}$ Rubin D. Myofascial trigger point syndromes: an approach to management. Arch Phys Med Rehabil 1981;62:107-10.

${ }^{13}$ Travell J. Identification of myofascial trigger point syndromes: a case of atypical facial neuralgia. Arch Phys Med Rehabil 1981;62:100-6.

${ }^{14}$ Bruckner FE. Frozen shoulder (adhesive capsulitis). $\mathcal{F} R$ Soc Med 1982; $75: 688-9$

${ }^{15}$ Lee PN, Lee M, Haq AMMM, Longton EB, Wright V. Periarthritis of the shoulder. Ann Rheum Dis 1974;33:116-9.

(Accepted 11 August 1983)

\title{
Multiple endocrine neoplasia associated with von Recklinghausen's disease
}

\author{
D F R GRIFFITHS, G T WILLIAMS， E D WILLIAMS
}

\begin{abstract}
Details were studied of three patients with duodenal carcinoid tumour in association with neurofibromatosis and phaeochromocytoma, and of four patients with duodenal carcinoid and either von Recklinghausen's disease or phaeochromocytoma. The rarity of these endocrine tumours, together with the unusual morphological features and somatostatin content of the two duodenal carcinoids examined, suggest that this combination of tumours is not a chance association.

It is suggested that this linkage of neurofibromatosis, phaeochromocytoma, and duodenal carcinoid is a specific multiple endocrine neoplasia syndrome.
\end{abstract}

\section{Introduction}

A variety of multiple endocrine neoplasia syndromes have been described, but at present three major types are accepted, usually referred to as types I, IIa, and IIb. Multiple endocrine neoplasia type I, first clearly defined in the 1950s, ${ }^{1}$ affects the anterior pituitary, parathyroids, pancreatic islets, and adrenal cortex, the glands showing a variable degree of adenomatous hyperplasia, adenomas, or carcinomas. ${ }^{2}$ It may be accompanied by carcinoid tumours, both bronchial and at other sites. ${ }^{3}$ Multiple endocrine neoplasia type IIa, the combination of

\footnotetext{
Department of Pathology, Welsh National School of Medicine, Heath Park, Cardiff CF4 4XN

D F R GRIFFITHS, MA, MRCP, senior registrar

G T WILLIAMS, MD, MRCPATH, senior lecturer

E D WILLIAMS, FRCP, FRCPATH, professor

Correspondence and reprint requests to: $\mathrm{Dr} G \mathrm{~T}$ Williams.
}

medullary carcinoma of the thyroid and phaeochromocytoma, ${ }^{4}$ is often referred to as Sipple's syndrome. ${ }^{5}$ Multiple endocrine neoplasia type IIb is the link between multiple mucosal neuromas, medullary carcinoma, and phaeochromocytoma. ${ }^{6}$ In types IIa and IIb both medullary carcinoma and"phaeochromocytoma may be bilateral, multifocal, and preceded by hyperplasia of thyroid $\mathrm{C}$ cells and phaeochromocytes respectively.

Many workers have reported the occurrence of tumours of more than one endocrine gland in the same patient or within the same family that do not fall into these recognised patterns, ${ }^{7} 8$ and it is often difficult to exclude the possibility of a chance association. We have recently seen an unusual combination of duodenal carcinoid, phaeochromocytoma, and neurofibromatosis and have subsequently found that a sufficient number of similar cases had been reported to make us believe that this is not a chance association and may be important in the management of patients.

\section{Details of patients}

Over the past three years we have seen four patients with tumours of the duodenum with unusual histopathological features, three of whom were referred from other hospitals. All four tumours were endocrine cell tumours (carcinoids) that reacted only weakly to normal silver impregnation techniques and had an unusual glandular pattern, and three of the tumours contained psammoma bodies. Three of the tumours were resected; they were strongly positive on immunolocalisation with an antibody to somatostatin (figure). This antibody had been shown to stain normal pancreatic D cells; the staining was abolished by preabsorption with somatostatin 14 . The fourth tumour was an incidental finding at necropsy and therefore unsuitable for somatostatin immunolocalisation.

We regarded these tumours as carcinoids, using the terminology recommended by the World Health Organisation international histological classification of tumours. ${ }^{10}$ They could be further subclassified as D cell carcinoids or so called somatostatinomas. We 


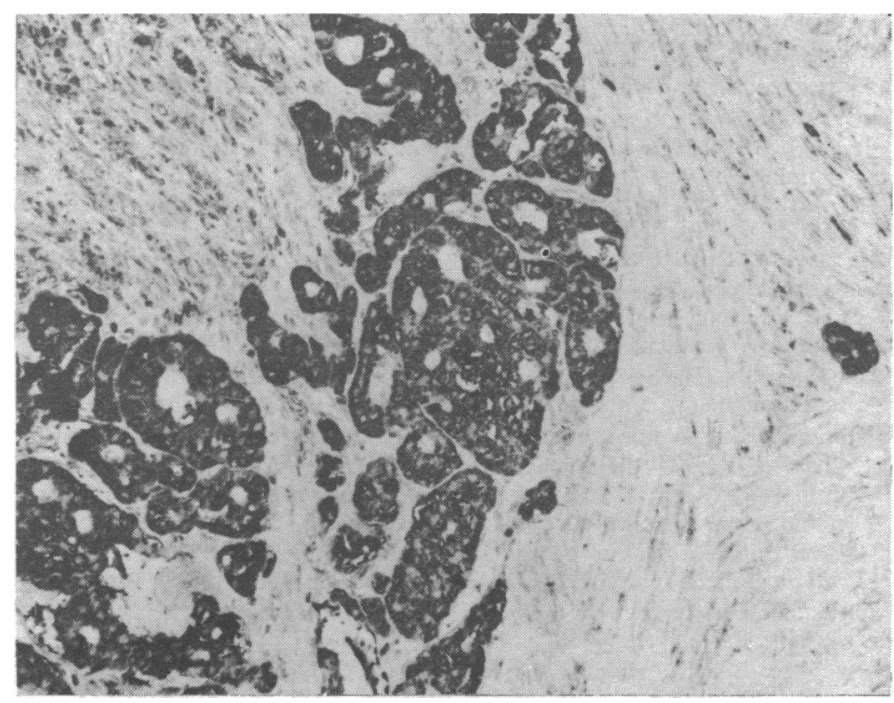

Case 2. Tumour cells show widespread and strong positivity; the glandular pattern is well seen. Immunoperoxidase technique, ${ }^{9}$ using antisomatostatin antibody. $\times 200$.

considered the possibility that they might be ectopic islet cell tumours, as D cells containing somatostatin occur in both the islets of the pancreas and the duodenum, but as there was no evidence of heterotopic pancreatic tissue this was unlikely. Two of the patients had neurofibromatosis and phaeochromocytoma. A search of the literature elicited five further similar cases of duodenal carcinoid together with phaeochromocytoma or neurofibromatosis, or both. The table summarises the clinical and pathological findings in these seven cases.

\section{Prevalence and features of the tumours}

Various tumours, many of neural origin, occur in association with von Recklinghausen's disease. Some of these tumours may be coincidental, but phaeochromocytoma is well known to occur more often than expected by chance in patients with von Recklinghausen's disease. Phaeochromocytoma is rare, and uncommon even in patients with von Recklinghausen's disease. The finding of seven cases of another rare tumour, a duodenal carcinoid (which is much less common than either an ileal or appendiceal carcinoid), in association with either von Recklinghausen's disease or phaeochromocytoma or both conditions together is clearly outside the bounds of chance.
Two reviews of multiple endocrine lesions of "mixed type" have $\underset{\sim}{\tau}$ been published, ${ }^{78}$ but neither clearly delineates the complex we $\$ describe. A report from the Mayo Clinic of patients with islet cell $\stackrel{\varnothing}{\varrho}$ tumours and phaeochromocytoma is obviously relevant, particularly $c$ as the patients belonged to families with inherited phaeochromo- $\widehat{O}$ cytomas. $^{8}$ In that review, of the total of 13 patients with both pan- $\bar{J}$ creatic islet cell tumours and phaeochromocytomas, none came from $D$ families with von Recklinghausen's disease while six came from $\mathbb{Q}$ families with the von Hippel-Lindau syndrome. We therefore suggest that this syndrome is quite separate from the one we describe here.

We were able to study the morphological features of the duodenal tumour in cases 1 and 2 in our series. Both tumours showed an unusual glandular pattern and contained psammoma bodies and immuno- $\overrightarrow{0}$ reactive somatostatin. We have seen two similar tumours without evidence of phaeochromocytoma or von Recklinghausen's disease $\overline{\bar{\omega}}$ and believe that this glandular form of a carcinoid producing somato- $\vec{\Phi}$ statin is a specific entity. A glandular pattern was not seen in any of $\varrho$ the duodenal carcinoids reviewed by Soga and Tazawa ${ }^{17}$ and Jones and Dawson. ${ }^{18}$ The duodenal lesion is therefore of particular interest in its own right, and we shall describe its special features elsewhere.

\section{Discussion}

The prevalence of this association of von Recklinghausen's disease, phaeochromocytoma, and duodenal carcinoid is difficult to predict from the small number of reported cases. $\vec{f}$ Although phaeochromocytoma is commonly symptomatic, ? duodenal carcinoid may be difficult to diagnose in life. These $\vec{\omega}$ tumours may be discovered in three ways: they may have a $\nexists$ local effect-for example, obstructive jaundice; they may have 을 a systemic effect, due to hormone secretion, with or without or metastasis; or they may be found incidentally. Of the duodenal $Z$ tumours reviewed here, three produced symptoms (two obstructive jaundice and one upper abdominal pain) while the four others were found incidentally, two at laparotomy and two at necropsy. We suspect that several similar cases may have been missed in the past as a small tumour in the duodenum $\oplus$ might not be obvious even during a fairly careful exploration of the abdomen unless its presence is specifically sought. In addition, not enough is yet known about the possible functional role of these tumours. In the two cases we studied somatostatin was the major hormone identified in the tumour; we have no evidence that it was being secreted, as the presence of an $\mathbb{D}$ intestinal endocrine tumour was not suspected preoperatively and appropriate plasma studies were not carried out. The syndrome produced by excess production of somatostatin-namely, diabetes mellitus, diarrhoea, malabsorption, hypochlorhydria, and gall stones ${ }^{19}{ }^{20}$-is less well defined than that associated with

Details of patients

\begin{tabular}{|c|c|c|c|c|c|c|c|}
\hline Patient & Age & Sex & Clinical presentation & Duodenal tumour & Phaeochromocytoma & Neurofibromatosis & Outcome \\
\hline Case 1 & 60 & F & $\begin{array}{l}\text { Hypertension. Duodenal } \\
\text { tumour an incidental } \\
\text { finding at laparotomy }\end{array}$ & $\begin{array}{l}\text { Psammomatous and } \\
\text { glandular carcinoid in } \\
\text { 2nd part of duodenum. } \\
\text { Most cells containing } \\
\text { somatostatin, few with } \\
\text { gastrin }\end{array}$ & Bilateral & $\begin{array}{l}\text { Generalised, cutaneous, } \\
\text { familial }\end{array}$ & $\begin{array}{l}\text { Well } 18 \text { months } \\
\text { postoperatively }\end{array}$ \\
\hline Case $2^{*}$ & 49 & $\mathrm{~F}$ & $\begin{array}{l}\text { Dyspnoea and } \\
\text { hypertension. Duodenal } \\
\text { tumour an incidental } \\
\text { finding at laparotomy }\end{array}$ & $\begin{array}{l}\text { Psammomatous and } \\
\text { glandular carcinoid at } \\
\text { ampulla. Most cells } \\
\text { containing somatostatin, } \\
\text { few with insulin }\end{array}$ & Unilateral & $\begin{array}{l}\text { Widespread, cutaneous, } \\
\text { non-familial }\end{array}$ & $\begin{array}{l}\text { Both tumours resected. } \\
\text { Well postoperatively }\end{array}$ \\
\hline $\begin{array}{c}\text { Johnson and } \\
\text { Weaver }^{12}\end{array}$ & 53 & $\mathrm{~F}$ & Upper abdominal pain & $\begin{array}{l}2 \text { cm carcinoid in } \\
\text { ampulla of Vater }\end{array}$ & $\begin{array}{l}\text { Not noted (normal } \\
\text { urinary } \\
\text { vanillylmandelic acid } \\
\text { excretion) }\end{array}$ & Cutaneous & $\begin{array}{l}\text { Well } 18 \text { months after } \\
\text { resection of duodenal } \\
\text { tumour }\end{array}$ \\
\hline Barber ${ }^{13}$ & 30 & M & Obstructive jaundice & $\begin{array}{l}1.3 \mathrm{~cm} \text { diameter ampullary } \\
\text { carcinoid }\end{array}$ & Not noted & $\begin{array}{l}\text { Widespread, cutaneous, no } \\
\text { family history }\end{array}$ & $\begin{array}{l}\text { Duodenal tumour resected. } \\
\text { Well postoperatively }\end{array}$ \\
\hline $\begin{array}{l}\text { Weichert } \\
\text { et } a l^{14}\end{array}$ & 34 & $\mathrm{~F}$ & Obstructive jaundice & $\begin{array}{l}\text { Two duodenal carcinoids, } \\
\text { one obstructing } \\
\text { ampulla of Vater }\end{array}$ & Not noted & $\begin{array}{l}\text { "Multiple } \\
\text { neurofibromatosis" }\end{array}$ & $\begin{array}{l}\text { Well } 18 \text { months after } \\
\text { resection of duodenal } \\
\text { tumours }\end{array}$ \\
\hline $\begin{array}{l}\text { Lee and } \\
\text { Garber }^{15}\end{array}$ & 72 & $M$ & $\begin{array}{l}\text { Duodenal tumour found } \\
\text { at necropsy }\end{array}$ & $\begin{array}{l}\text { Duodenal carcinoid } \\
2 \times 1 \times 1 \mathrm{~cm}\end{array}$ & $\begin{array}{c}\text { Unilateral, } 3 \mathrm{~cm} \\
\text { diameter }\end{array}$ & $\begin{array}{l}\text { Generalised, cutaneous, } \\
\text { and visceral }\end{array}$ & \\
\hline $\begin{array}{r}\text { Barnard and } \\
\text { Jacobson }^{16}\end{array}$ & 13 & $\mathrm{~F}$ & $\begin{array}{l}\text { Hypertension. Duodenal } \\
\text { tumour found at } \\
\text { necropsy }\end{array}$ & $\begin{array}{l}1 \text { cm diameter carcinoid at } \\
\text { "duodenal papilla" }\end{array}$ & $\begin{array}{l}\text { Unilateral with } \\
\text { multiple metastases }\end{array}$ & Not noted & $\begin{array}{l}\text { Postoperative death after } \\
\text { resection of } \\
\text { phaeochromocytoma }\end{array}$ \\
\hline
\end{tabular}

*Also reported on by Cantor et al. ${ }^{11}$ 
several other hormones. Measurement of the plasma concentrations of regulatory peptides in patients with both neurofibromatosis and phaeochromocytoma may identify those with duodenal carcinoids and throw light on the functional capacity of these tumours.

This association of tumours appears to be important in the clinical management of patients. We believe that in any patient with neurofibromatosis or phaeochromocytoma who also has diarrhoea, diabetes, or cholelithiasis the possibility of a duodenal carcinoid that produces somatostatin should be considered. Obstructive jaundice in a similar patient could also be caused by duodenal carcinoid, either owing to its obstructing the ampulla or as a result of cholelithiasis related to secretion of somatostatin.

Clearly, more information is needed about this rarely reported combination of tumours; it is probably genetically determined, but in only one of the cases of von Recklinghausen's disease was a family history obtained, and there was no evidence that any of the duodenal carcinoids or phaeochromocytomas was inherited. We hope, however, that this preliminary report will lead to the discovery of more cases of this interesting syndrome so that its true importance may be assessed. There appear to be three broadly separate neuroendocrine tumour syndromesnamely, multiple mucosal neuromas with medullary carcinoma and phaeochromocytoma (multiple endocrine neoplasia type IIb), neurofibromatosis with phaeochromocytoma and duodenal carcinoid, and the von Hippel-Lindau syndrome with phaeochromocytoma and islet cell tumours. If these latter two entities can be clearly established it may be possible to regard them as multiple endocrine neoplasia types IIIa and IIIb respectively.

We thank Dr I D Ansell and Dr D C Banks of the City Hospital, Nottingham, for bringing case 1 to our attention, and Dr G D Powell, of Rotherham District General Hospital, for referring the tumours in case 2.

\section{References}

'Werner P. Genetic aspects of adenomatosis of endocrine glands. Am $\mathcal{J}$ Med 1954;16:363-71.
2 Ballard HS, Frame B, Hartsock RJ. Familial multiple endocrine adenomapeptic ulcer complex. Medicine (Baltimore) 1964;45:481-516.

${ }^{3}$ Williams ED, Celestin LR. The association of bronchial carcinoid and pleuriglandular adenomatosis. Thorax $1962 ; 17: 120-7$.

4 Williams ED. A review of 17 cases of carcinoma of the thyroid and phaeochromocytoma. $\mathcal{F}$ Clin Pathol 1965;18:288-92.

${ }^{5}$ Sipple JH. The association of phaeochromocytoma with carcinoma of the thyroid gland. Am 7 Med $1961 ; 31: 163-6$.

6 Williams ED, Pollock DH. Multiple mucosal neuromata with endocrine tumours; a syndrome allied to von Recklinghausen's disease. $\mathcal{F}$ Pathol Bacteriol 1966;91:71-80.

${ }^{7}$ Hansen OP, Hansen M, Hansen HH, Rose B. Multiple endocrine adenomatosis of mixed type. Acta Med Scand 1976;200:327-31.

${ }^{8}$ Carney JA, Go VLW, Gordon H, Northcutt RC, Pearse AGE, Sheps SG. Familial phaeochromocytoma and islet cell tumour of the pancreas. Am F Med 1980;68:515-21.

9 Jasani B, Wynford-Thomas D, Williams ED. Use of monoclonal antihapten antibodies for immunolocalisation of tissue antigens. $\mathcal{f}$ Clin Pathol $1981 ; 34: 1000-2$.

10 Williams ED, Siebenmann R, Sobin LH. International histological classification of tumours. Histological typing of endocrine tumours. Geneva World Health Organisation, 1980.

${ }^{11}$ Cantor AM, Rigby CC, Beck PR, Mangion D. Neurofibromatosis, phaeochromocytoma, and somatostatinoma. Br Med $\mathcal{f} 1982 ; 285: 1618-9$.

12 Johnson L, Weaver M. Von Recklinghausen's disease and gastrointestinal carcinoids. FAMA $1981 ; 245: 2496$.

${ }^{13}$ Barber PV. Carcinoid tumour of the ampulla of Vater associated with cutaneous neurofibromatosis. Postgrad Med f 1976;52:514-7.

${ }^{14}$ Weichert RF, Roth LM, Krementz ET, Hewett RL, Drapanus T. Carcinoid-islet cell tumours of the duodenum, report of twenty-one cases. Am $\mathcal{F}$ Surg 1971;121:195-205.

${ }^{15}$ Lee HY, Garber PE. Von Recklinghausen's disease associated with phaeochromocytoma and carcinoid tumour. Ohio State Med $\mathcal{F} 1970$; 66:583-6.

${ }^{16}$ Barnard PJ, Jacobson L. Malignant phaeochromocytoma associated with argentaffinoma and hypotensive crisis, report of a case. Cent Afr $\mathcal{7} \mathrm{Med}$ $1965 ; 11: 185-90$

17 Soga J, Tazawa K. Pathological analysis of carcinoids, histological reevaluation of 62 cases. Cancer 1971;28:990-8.

${ }^{18}$ Jones RA, Dawson IMP. Morphology and staining patterns of endocrine cell tumours in the gut, pancreas and bronchus and their possible significance. Histopathology 1977;1:137-50.

${ }^{19}$ Krejs GJ, Orci L, Conlon JM, et al. Somatostatinoma syndrome, biochemical, morphological and clinical features. $N$ Engl f Med 1979; 301 : 285-92.

${ }^{20}$ Friesen SR. Tumours of the endocrine pancreas. N Engl f Med 1982; $306: 580-90$.

(Accepted 11 August 1983)

\section{SHORT REPORTS}

\section{Case of ectopic pregnancy after postcoital contraception with ethinyloestradiol-levonorgestrel}

A combination of $0.1 \mathrm{mg}$ ethinyloestradiol and $0.5 \mathrm{mg}$ levonorgestrel (two tablets of Eugynon 50 or Ovran) given within 72 hours after exposure to the risk of pregnancy and repeated 12 hours later has a contraceptive success rate of around $98 \%{ }^{1}$ As this so called Yuzpe regimen is thought to act primarily at the uterine level rather than to inhibit ovulation an ectopic pregnancy is more likely when the treatment fails, especially if there is pre-existing tubal damage. There is also the possibility of an effect on tubal function which could contribute to the risk of ectopic pregnancy.

We report a case of tubal pregnancy after the Yuzpe regimen.

\section{Case history}

A 34 year old para $0+1$ presented requesting postcoital treatment 34 hours after a single episode of unprotected intercourse on day 12 of her cycle. She had omitted using her cap on that occasion. She gave a history of salpingitis at the age of 20 and a termination of pregnancy at the age of 24 She was given a counselling leaflet and was counselled by an experienced family planning doctor. Vaginal examination showed no abnormality. She was treated according to the Yuzpe regimen and did not experience nausea or vomiting.
At follow up four weeks later she reported an episode of vaginal bleeding which was light but similar to her normal period, lasting for eight days. This had started 12 days after the postcoital treatment. Four days after finishing her "period" ( 24 days after treatment) she had started bleeding again and experienced severe lower abdominal pain, for which she attended a casualty department at $4 \mathrm{am}$. Although she mentioned the postcoital treatment, vaginal examination showed no mass or tenderness and she was discharged with no specific arrangement for follow up.

The pelvic pain persisted, and when seen by one of us (JG) 32 days after the original treatment, and 44 days after her last normal period, there was a tender left adnexal mass about $3 \mathrm{~cm}$ diameter. At laparoscopy a left tubal pregnancy was diagnosed. The whole tube was distended with a haematosalpinx complicating a pre-existing hydrosalpinx. There was a small haemoperitoneum. The right tube and ovary were normal. A left salpingectomy was done, and tubal pregnancy was confirmed histologically. The patient made an uneventful recovery.

\section{Comment}

Ectopic pregnancies have been reported after stilboestrol ${ }^{2}$ and diethylstilboestrol. ${ }^{3}$ We also know of a case after ethinyloestradiol that occurred in Holland in 1974. Morris and Van Wagenen ${ }^{4}$ reviewed 9000 cases of postcoital oestrogen contraception (high dose, five day courses) and found 29 reported pregnancies: three were ectopic. Though in two of these inadequate doses of oestrogens had been given, the risk of an ectopic pregnancy was calculated as $10 \%$. Yuzpe argues ${ }^{5}$ that the high risk of ectopic gestation quoted is misleading, as postcoital contraception appears to reduce the number of 